\title{
Seasonal variations of accumulation and the isotope record in ice cores: a study with surface snow samples and firn cores from Neumayer station, Antarctica
}

\author{
Elisabeth SCHLOSSER, ${ }^{1}$ Hans OERTER ${ }^{2}$ \\ ${ }^{1}$ Institute of Meteorology and Geophysics, University of Innsbruck, Innrain 52, A-6020 Innsbruck, Austria \\ E-mail: elisabeth.schlosser@uibk.ac.at \\ ${ }^{2}$ Alfred Wegener Institute for Polar and Marine Research, P.O. Box 120161, D-27568 Bremerhaven, Germany
}

\begin{abstract}
At the German wintering base Neumayer, an intensive glacio-meteorological programme has been carried out during the last two decades. A complete meteorological dataset and data from surface snow samples, snow pits, firn cores and weekly accumulation measurements from a stake array are available. We first investigated the attenuation of the seasonal $\delta^{18} \mathrm{O}$ signal due to water-vapour diffusion in the snow pack. A comparison of surface snow samples and firn cores of different ages shows that only onethird of the seasonal $\delta^{18} \mathrm{O}$ signal of the surface snow samples remains in the cores after the first year. No further significant change in the amplitude of the seasonal $\delta^{18} \mathrm{O}$ signal is found later. Changes in the seasonal distribution of accumulation can lead to a bias in ice-core properties. This is studied on a short time-scale, using high-time-resolution data of accumulation, stable-isotope ratios and air temperature. Mean annual $\delta^{18} \mathrm{O}$ values from firn cores are not well correlated to annual mean air temperatures. However, the correlation is improved considerably by calculating an annual mean air temperature using monthly mean temperatures weighted by monthly accumulation. At Neumayer, it is mainly the cyclonic activity in late winter/early spring that determines whether and how the core data are biased.
\end{abstract}

\section{INTRODUCTION}

The reliability of ice-core interpretation, especially concerning the temperature $-\delta^{18} \mathrm{O}$ relationship, is highly dependent on a thorough understanding of the physical processes involved in accumulation, namely, moisture origin, moisture transport and formation of precipitation (Dansgaard, 1964; Peel and others, 1988; Jouzel and others, 1997). The temperature $-\delta^{18} \mathrm{O}$ relationship has been the subject of numerous studies (Picciotto and others, 1960; Jouzel and others, 1983, 1997; Robin, 1983; Reinwarth and others, 1985; Peel and others, 1988; Peel, 1992; Jones and others, 1993; Graf and others, 1994, 2002; Isaksson and Karlén, 1994). In spite of the highly complex processes involved, a linear relationship is found between mean annual $\delta^{18} \mathrm{O}$ of snow/ice and the annual mean air temperature at the deposition site (cf., e.g., Graf and others, 2002). This relationship is determined empirically using mean $\delta^{18} \mathrm{O}$ values and $10 \mathrm{~m}$ firn temperatures, as a measure of the annual mean air temperature, from different sites. For interpretation of isotope profiles from ice cores it is assumed that this spatial $\delta-T$ relationship also holds for temporal variations of $\delta^{18} \mathrm{O}$. However, changes in the seasonality of accumulation can greatly affect the mean annual $\delta^{18} \mathrm{O}$ value of the snow, which would lead to a bias in the temperature derived from ice cores. Only a few field data are available which could be used to explain or quantify this bias. Whereas Noone and Simmonds (1998) and Noone and others (1999) used the European Centre for Medium-Range Weather Forecasts (ECMWF) re-analysis data to study these effects, in this study we use data from a coastal Antarctic site for our investigation on a time-scale of years to decades.

At the German wintering base Neumayer, situated at $70^{\circ} 39^{\prime} \mathrm{S}, 8^{\circ} 15^{\prime} \mathrm{W}$, on Ekströmisen, on the coast of Dronning Maud Land (DML), an intensive glacio-meteorological programme has been carried out during the last two decades. A complete meteorological dataset including upper-air data, as well as data from surface snow samples, snow pits and firn cores $\left(\delta^{18} \mathrm{O}, \delta \mathrm{D},{ }^{3} \mathrm{H}\right.$, chemical properties) and weekly accumulation measurements from a stake array, are available (Schlosser and others, 1999). This unique dataset is used for a comprehensive study of the accumulation conditions on Ekströmisen. A comparison of surface snow samples and firn cores of different ages yields information about the attenuation of the seasonal signal of the isotope ratio due to water-vapour diffusion in the snowpack. The effect of changes in seasonality of accumulation on the annual mean $\delta^{18} \mathrm{O}$ value is also investigated. Implications of these results for larger time-scales are discussed.

\section{DATA}

Glaciological studies have been carried out on Ekströmisen since the pre-site survey expedition for the wintering base "Georg-von-Neumayer" ( GvN) in the austral summer of 1979/80. In March 1981, when construction of the base was complete, a stake array was set up $700 \mathrm{~m}$ south of the station building. Since then the number of stakes and the site of the 
Table 1. Shallow firn cores and snow pit used in this study

\begin{tabular}{llccc}
\hline Core/pit & \multicolumn{1}{c}{ Location } & Date & Length & Time period \\
& & & $\mathrm{m}$ & \\
& & & & \\
\hline AB01 & GVN & Feb. 1980 & 12.06 & $1963-79$ \\
B04 & GVN & Feb. 1982 & 52 & $1892-81$ \\
E002 & Km2 South & $1986 / 87$ & 10.11 & $1972-86$ \\
E040 & Km40 South & $1986 / 87$ & 9.66 & $1971-86$ \\
FB0189 & Neumayer & 27 Dec. 89 & 10 & $1975-88$ \\
FB0192 & Neumayer & 14 Mar. 92 & 9.8 & $1978-91$ \\
FB0595 & Neumayer & 11 Mar. 95 & 10.71 & $1980-93$ \\
FB0198 & 15km South & 04 Dec. 97 & 27.8 & $1955-97$ \\
SS0283 (pit) & GVN & 19 Feb. 82 & 4.15 & $1976-82$ \\
& & & & \\
\hline
\end{tabular}

array have been slightly changed, but accumulation has been measured continuously on a weekly basis, except for the wintering year 1984, during which the stakes were read only monthly. In 1992, a new base, "Neumayer", was built about $7 \mathrm{~km}$ southeast of GvN. A new stake array was set up $1 \mathrm{~km}$ south of the new base, and the old and new stake arrays were run simultaneously for about 2 years. The quadratic array consists of 25 metal stakes about $2 \mathrm{~m}$ long. A small amount of melting is observed during summer at the snow surface, but the stakes remained frozen to the surrounding snow at deeper levels and did not melt in. Settling of the snow cover is negligible in the weekly measurements compared to ablation due to wind erosion.

Snow pits were dug and shallow firn cores were taken at irregular time intervals, mostly in summer. Additionally, snow surface samples were taken after precipitation events. The stable-isotope ratios $\left(\delta^{18} \mathrm{O}, \delta^{2} \mathrm{H}\right)$, and sometimes also the tritium $\left({ }^{3} \mathrm{H}\right)$ of these samples and of the snow pits and firn cores, were analyzed. The cores were dated using the seasonality of the stable-isotope stratigraphy, sometimes supplemented by tritium measurements, and in one case, by dielectric profiling (Schlosser and Oerter, 2002). Table 1 gives details of all the firn cores and a snow pit used in this study. Details of the glaciological measurements at Neumayer can be found in Schlosser and others (1999).

As well as the glaciological measurements, the meteorological observatory at Neumayer provides measurements of all important meteorological parameters including upperair data (König-Langlo and Marx, 1997).

\section{ATTENUATION OF THE SEASONAL VARIATION OF $\delta^{18} \mathrm{O}$}

Before discussing the $\delta^{18} \mathrm{O}$-temperature relationship, we will look at the isotope profiles, especially at the attenuation of the amplitude of the seasonal $\delta^{18} \mathrm{O}$ signal.

Mass exchange by diffusion of water vapour and sintering in the upper layers of the firn smooths the isotopic profile over a period ranging from months to decades (Johnsen, 1977; Johnsen and Robin, 1983). According to Johnsen (1977), this process is no longer important when the density exceeds $550 \mathrm{~kg} \mathrm{~m}^{-3}$, corresponding to the closest random packing of grains.

At Neumayer, the density can exceed $550 \mathrm{~kg} \mathrm{~m}^{-3}$ at depths of about $2-6 \mathrm{~m}$, corresponding to an age of about $3-10$ years. The firn-ice transition $\left(830 \mathrm{~kg} \mathrm{~m}^{-3}\right)$ is found at depths of about $50 \mathrm{~m}$ (Schlosser and others, 1999).

In order to investigate the attenuation of the seasonal $\delta^{18} \mathrm{O}$ signal in the snowpack with time, we first compared

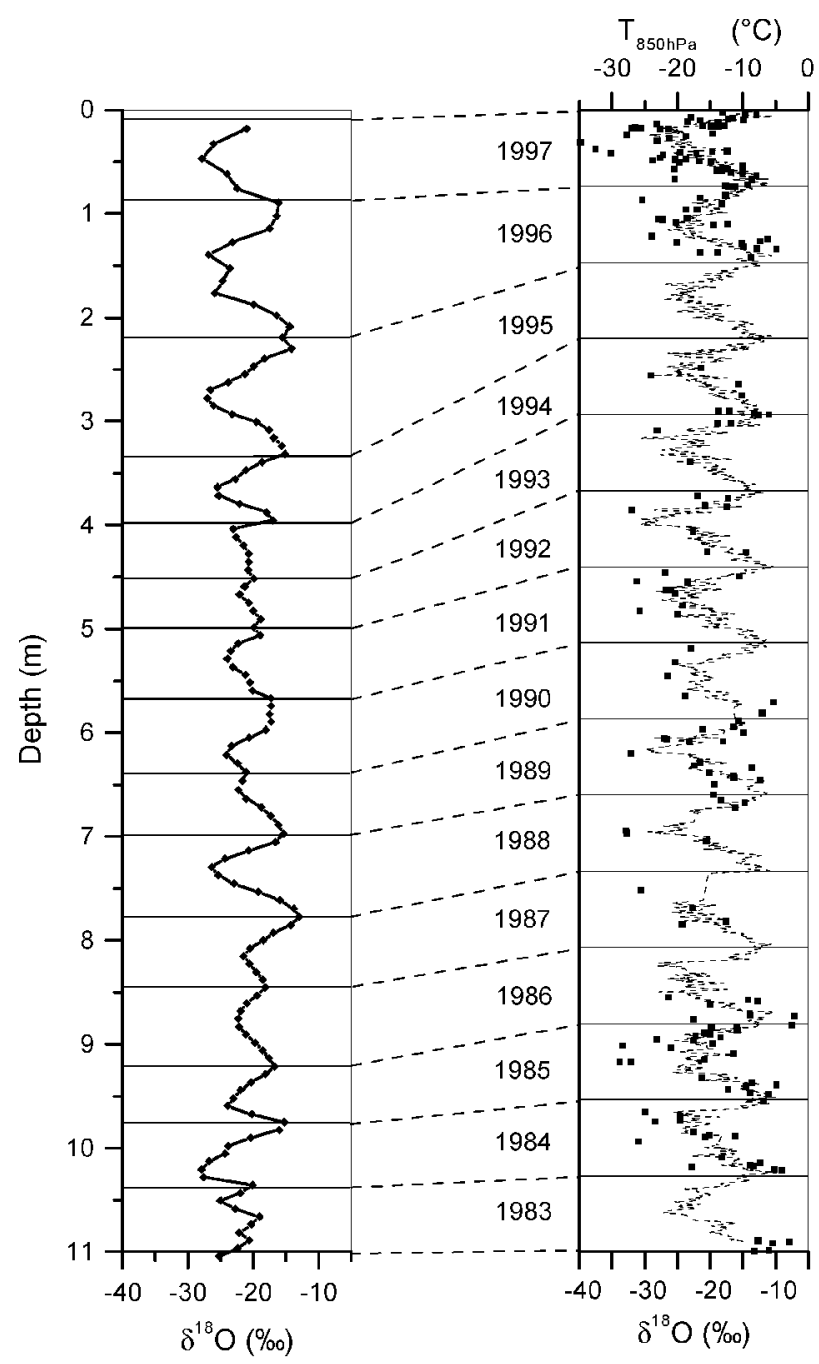

Fig. 1. $\delta^{18} \mathrm{O}$ of firn core FB0198 (left, bold line) and of surface snow samples (right, squares), 1981-98. Together with the latter, temperature at the $850 \mathrm{hPa}$ level is given (right, dashed line).

the yearly amplitude of the $\delta^{18} \mathrm{O}$ values of the surface snow samples to the yearly amplitudes found in core FB0198. Secondly, the amplitudes of the seasonal $\delta^{18} \mathrm{O}$ variation of several cores drilled in different years were compared.

Figure 1 shows the $\delta^{18} \mathrm{O}$ value of core FB0198 and of the surface snow samples taken between 1983 and 1997 (accuracy of the isotope measurements: $\pm 0.1 \%$ ), as well as the air temperature at the $850 \mathrm{hPa}$ level.

The number of surface snow samples per year is highly variable. The original idea was to take samples only after snowfall events little affected by wind, in order to avoid mixing of the snow due to snowdrift. Such events seldom occur, however, so in recent years snow samples have been taken after each major precipitation event, whether snowdrift was observed or not. Also, a higher number of samples were taken in 1984 and 1985; this depended on the assessment of the wintering meteorologists. Clearly, the amplitude of the annual $\delta^{18} \mathrm{O}$ cycle is much higher in the surface snow samples than in the firn core. For each year, the differences between winter minimum and both summer maxima were calculated. In the core, these differences were $2.2-13.4 \%$ (mean $=7.6 \%, \sigma=$ $3.2 \%$ ), whereas the surface snow samples show differences of $14.6-29 \%$ o (mean $=22.4 \%$ o, $\sigma=4.3 \%$ o).

For years with few surface snow samples, only the minimum amplitude could be determined, which is, however, still much larger than the amplitudes observed in the core. A small part of this difference might be due to the sampling 


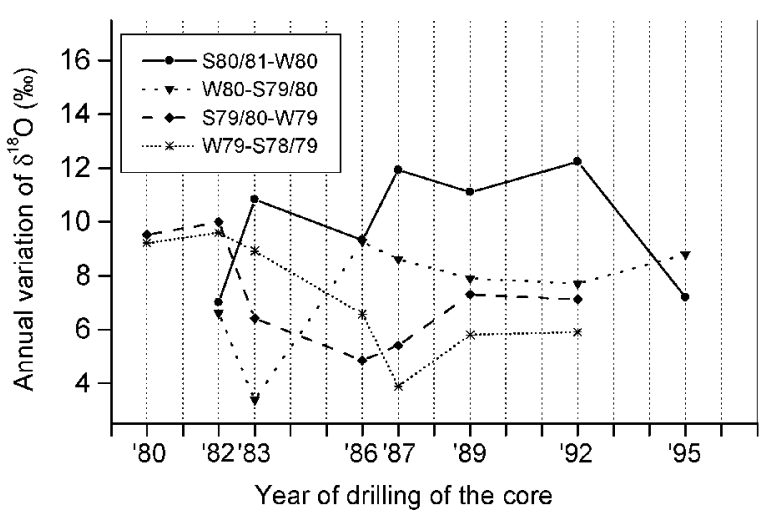

Fig. 2. Yearly variations of $\delta^{18} \mathrm{O}$ derived from seven firn cores and one deep snow pit of different age ( see Table 1). For each core (pit) the differences between winter minimum and summer maxima were calculated for each year between summer 1978/ 79 and summer 1980/81.

size of the core samples, which was $2-3 \mathrm{~cm}$ for the $10 \mathrm{~m}$ cores, and about $8 \mathrm{~cm}$ for the $27.8 \mathrm{~m}$ long core FB0198, which caused a certain smoothing of the signal. But the difference is much too large to be attributable solely to the measuring method. Only about one-third of the amplitude measured in the surface snow samples remains in the core. Johnsen (1977) calculates the change of amplitude of annual $\delta^{18} \mathrm{O}$ cycles in firn using the following equation:

$$
A_{\delta}=A_{\delta \mathrm{S}} \exp \left(-2 \pi^{2} L^{2} / \lambda^{2}\right),
$$

where $A_{\delta}$ is the final amplitude of an ${ }^{18} \mathrm{O}$ cycle at depths below that of the critical density $\left(550 \mathrm{~kg} \mathrm{~m}^{-3}\right), A_{\delta \mathrm{S}}$ is the initial amplitude in a surface layer of equivalent ice thickness $\lambda$, and $L$ is the mean total diffusion leng th of water molecules in firn. With $\lambda=350 \mathrm{~mm}$ ice equivalent (mean annual accumulation 1981-97 in core FB0198) and $L=80 \mathrm{~mm}$ ice equivalent (Johnsen, 1977), Equation (1) yields a reduction in the amplitude of $\delta^{18} \mathrm{O}$ cycles by about $65 \%$. This fits well with the observed mean ratio of $\delta^{18} \mathrm{O}$ amplitudes found in core FB0198 to the amplitudes in the surface sample, which is 0.36 .

The oldest firn core from the vicinity of Neumayer was taken in 1980, and the most recent one in 1998. This enables us to compare cores with an age difference up to 18 years. By comparing the amplitudes of the corresponding seasonal cycles of $\delta^{18} \mathrm{O}$ of different cores we investigated the attenuation of the seasonal signal. The years 1978-80 show a typical signal, which can be easily recognized in most cores. The year 1979 shows a fairly large amplitude and a relatively low winter minimum. In 1978, the amplitude was considerably smaller and the winter minimum higher, and 1980 shows a typical slightly asymmetrical shape with a secondary minimum value of the $\delta^{18} \mathrm{O}$ profile. The amplitudes of the $\delta^{18} \mathrm{O}$ for these years were compared for seven different firn cores and one deep snow pit taken/dug between 1980 and 1998.

Figure 2 shows the yearly amplitudes of $\delta^{18} \mathrm{O}$ between summer 1978/79 and summer 1980/81. The years on the $x$ axis correspond to the drilling/digging date of the respective cores/pit. No systematic decrease of the $\delta^{18} \mathrm{O}$ amplitude with age was found. At South Pole, Jouzel and others (1983) compared the $\delta^{18} \mathrm{O}$ amplitudes of snow from different snow pits taken between 1958 and 1978. During this 20 year period, they found no significant smoothing of the isotope signal either. Thus we conclude that the main part of attenuation of the seasonal signal of $\delta^{18} \mathrm{O}$ occurs during the first months of the snow metamorphism.

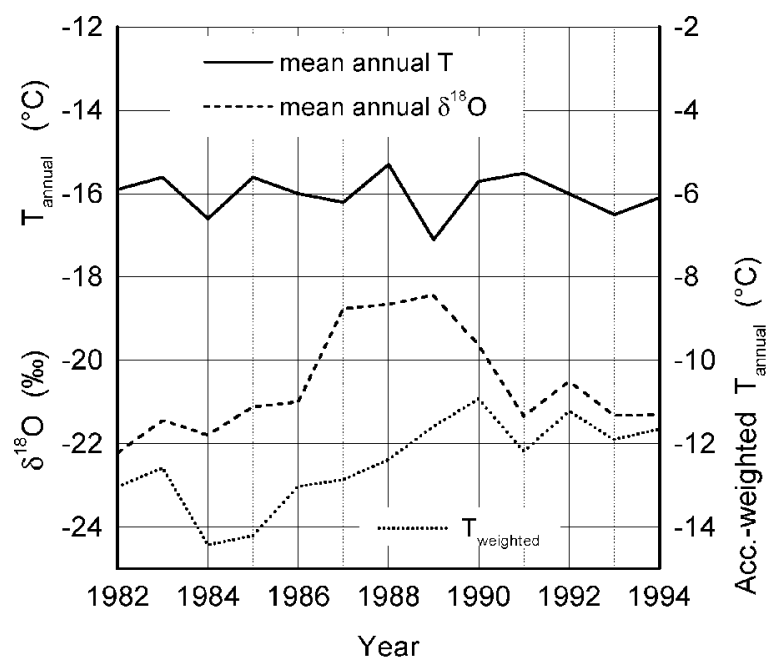

Fig. 3. Mean annual air temperature at Neumayer and mean annual $\delta^{18} O$ (average of FB0189, FB0292, FB0198). Additionally, the mean annual air temperature calculated using monthly mean temperatures weighted by monthly accumulation for 1982-94 is shown (explanation in the text).

\section{INFLUENGE OF SEASONALITY OF AGGUMULA- TION ON ANNUAL MEAN $\delta^{18} \mathrm{O}$}

In this study we investigate the bias that can occur in temperature derived from $\delta^{18} \mathrm{O}$ profiles of ice cores due to temporally irregular snow-deposition patterns. Based on an earlier study (Schlosser, 1999), but with extended data material, we investigated how changes in the seasonal variability of accumulation can influence the annual mean $\delta^{18} \mathrm{O}$ value in the cores.

Figure 3 shows the mean annual air temperature at Neumayer and the mean annual $\delta^{18} \mathrm{O}$ values for the years 1982-94, calculated as an average of the three shallow firn cores FB0198, FB0189 and FB0392. Schlosser and Oerter (2002) show that in spite of the high spatial variability of accumulation, the $\delta^{18} \mathrm{O}$ values of different cores are well correlated. Thus we assume that the mean of the three cores represents a common signal. Whereas the annual mean air temperature does not show large variations, the $\delta^{18} \mathrm{O}$ values vary considerably. The correlation between the annual means of temperature and stable-isotope content is fairly weak. The minimum temperature even corresponds to the maximum $\delta^{18} \mathrm{O}$ value. This can be understood by investigating the seasonal distribution of accumulation. Figure 4 shows the mean monthly accumulation measured at the stake array at Neumayer for the years 1982-96, separately for isotopically clearly "warm" years with $\delta^{18} \mathrm{O}>-20 \%$ (1981, 1987-90) and for isotopically clearly "cold" years with $\delta^{18} \mathrm{O}<-21 \%$ o $(1982$ $86,1991,1993,1994)$. The mean $\delta^{18} \mathrm{O}$ value of all years is $-20.6 \%$, so we chose the threshold $-20 \%$ and $-21 \%$ o respectively. Years with $-21 \% 0<\delta^{18} \mathrm{O}<-20 \%$ were not included in the accumulation average. (Accumulation is given in $\mathrm{cm}$ snow to avoid possible errors in calculation of the water equivalent due to uncertainties in snow density.) From summer to mid-winter, there are no striking differences between the seemingly "warmer" and "colder" years. However, in late winter/early spring, accumulation is considerably lower in years with high mean isotope ratios than in the years with values below $-21 \%$. This corresponds well to the monthly mean surface pressure at Neumayer, which is shown in Figure 5 for the same years as grouped in Figure 4. High accumulation values in late winter/early spring correspond to low 


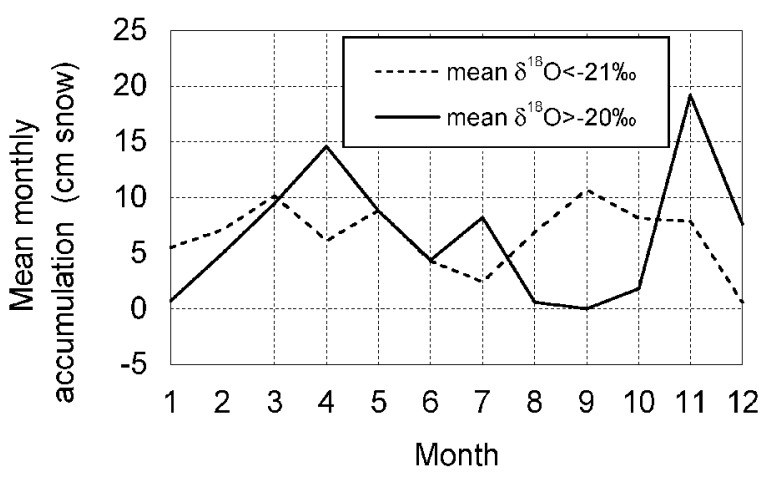

Fig. 4. Mean monthly accumulation at stake array Neumayer, 1982-96, for isotopically "warm" years with $\delta^{18} O>-20 \%$ o $(n=5)$ and isotopically "cold" years with $\delta^{18} O<-21 \%$ $(n=8)$.

pressure and vice versa. Since accumulation and thus precipitation at Neumayer is mainly connected to cyclonic activity, low pressure means high cyclonic activity and thus high amounts of accumulation. The contribution of the relatively cold months, August, September and, to a lesser degree, October, to the accumulation and thus to the annual mean $\delta^{18} \mathrm{O}$ is comparatively small in the seemingly "warmer" years. This leads to higher annual mean isotope values in these years than in the years with a more even accumulation distribution.

Although the mean annual temperature at Neumayer has varied only slightly during the past two decadesdeviations from the average $\left(-15.8^{\circ} \mathrm{C}\right)$ seldom exceed $1{ }^{\circ} \mathrm{C}$ - with no significant trend observed, the difference between the highest and the lowest mean annual $\delta^{18} \mathrm{O}$ value from the cores amounts to 4\%. This would lead to the assumption of a temperature variation of about $3.3^{\circ} \mathrm{C}$, using a gradient of $1.2 \%{ }^{\circ} \mathrm{C}^{-1}$ as was found by Oerter and others (1999) for Ekströmisen.

Cyclonic activity is mainly dependent on the position of the circumpolar trough whose position and strength undergoes a marked semi-annual oscillation. It is usually deepest and closest to the Antarctic continent in the equinoctial seasons (Van Loon, 1967; King and Turner, 1997). The comparison of monthly storm tracks from the ECMWF analyses for AugustOctober shows that in years with low accumulation in late winter/early spring the circumpolar trough was situated farther to the north than is usual for this time of the year. Thus fewer and weaker low-pressure systems passed Neumayer. During the seemingly "warm" years, the number of cyclones moving over Neumayer was lower than in the "cold" years, and the systems passing to the north of Neumayer from west to east were farther away in these years, leading to less precipitation at Neumayer. In the "warm" years, also, the storm tracks often ended near Neumayer, meaning that the cyclones were already occluded and did not bring much precipitation.

To further investigate the influence of seasonal distribution of accumulation on the mean isotopic record in the cores, a weighted mean annual temperature was calculated using mean monthly temperature values that were weighted by monthly accumulation amounts. The weighted annual mean air temperature, as displayed in Figure 3, was smoothed by a 5 year running mean. It is much better correlated $(r=0.38$, $n=13)$ to the mean annual $\delta^{18} \mathrm{O}$ than the non-weighted temperature $(r=-0.13, n=13)$. Still, the correlation is not really good, which means that other processes are involved that influence the $\delta^{18} \mathrm{O}$ in the core. Correlation coefficients should be considered with care because of the shortness of the

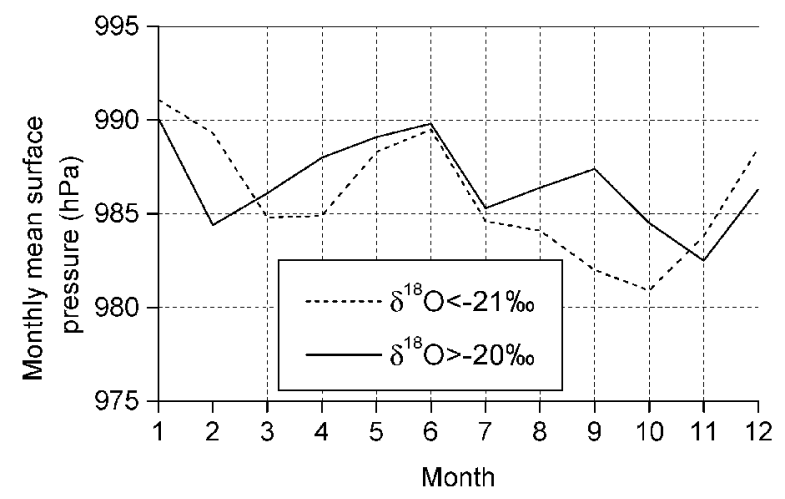

Fig. 5. Mean monthly surface pressure at Neumayer for the same years as grouped in Figure 4.

time series. Pfaff (1993) correlated monthly mean values of air temperature and monthly mean $\delta^{18} \mathrm{O}$ values of freshly fallen surface snow samples taken during the period 1981-90. The best correlation $(r=0.93)$ was seen between the temperature at the lifting condensation level and the $\delta^{18} \mathrm{O}$ values. Using the temperature at the $850 \mathrm{hPa}$ level, the correlation coefficient was 0.88 (cf. Fig. 1).

\section{DISGUSSION}

In this study, accumulation and meteorological data were used to study how the interannual variability of seasonality of accumulation influences the annual mean $\delta^{18} \mathrm{O}$ value of snow. On this small time-scale the varying synoptic conditions cause an irregular accumulation distribution, which leads to an overweighting of certain months in the annual mean of $\delta^{18} \mathrm{O}$.

On larger time-scales (centuries or millennia), this effect will be eliminated by averaging the mean $\delta^{18} \mathrm{O}$ value over longer time periods. However, if there is a systematic change in the general atmospheric circulation and thus in mean storm tracks, a systematic change in seasonality of accumulation will also occur. This is of little importance at sites where clear-sky precipitation is the main contributor to accumulation, such as Dome C and Vostok (Schwerdtfeger, 1984) where accumulation is distributed fairly evenly over the year. However, studies using EGMWF re-analysis data (Noone and others, 1999) and the short time series from DML automatic weather stations (Reijmer and Van den Broeke, 2001), respectively, have shown that at the European Project for Ice Coring in Antarctica (EPICA) DML drilling site $\left(75^{\circ} \mathrm{S}, 0^{\circ} \mathrm{E}\right)$, a non-negligible part of precipitation in DML is caused by frontal activity. Thus a few high-precipitation days can yield a large proportion of the annual accumulation. This is because the distance to the coast $(550 \mathrm{~km})$ is fairly short for an inland station and, more importantly, because DML is affected by cyclogenesis on the leeward side of the Antarctic Peninsula/South America. Usually such high-precipitation events are connected to amplified upper-level planetary waves that direct warm, moist air far to the south (Noone and others, 1999). A change in atmospheric circulation and thus in the frequency of occurrence of such conditions can lead to a bias in the isotopic record from ice cores. How far upstream of the drilling site the influence of such warm-air intrusions combined with precipitation reaches, and whether the deeper parts of the core might be affected, has still to be investigated.

Model results (Krinner, 1997) suggest a general decrease in cyclonic activity around Antarctica during the Last Glacial Maximum (LGM). However, a significant increase of cyclonic 
activity is found in the Weddell Sea due to significantly increased lee cyclogenesis east of the Antarctic Peninsula caused by the peninsula's higher LGM model topography (Krinner, 1997). Additionally, the position of the circumpolar trough changes from a semi-annual pattern today to a clear annual cycle during the LGM, with the southernmost position of the trough in summer, the northernmost in winter. The latter would also mean comparatively little winter precipitation in DML and thus a possible bias in temperatures derived from stable isotopes in the ice core.

\section{GONGLUSION}

The reliability of the interpretation of the isotopic record in ice cores is highly dependent on a thorough understanding of the physical processes involved in precipitation and thus in accumulation.

A comparison of surface snow samples and firn cores of different age from the vicinity of Neumayer shows that attenuation of the seasonal signal of the isotope ratio due to water-vapour diffusion in the snow pack occurs mainly during the first months of snow metamorphism. Only about onethird of the amplitude of the seasonal variation of the $\delta^{18} \mathrm{O}$ values found in samples from freshly fallen surface snow is preserved in the firn cores. Amplitudes within layers of the same deposition year but sampled in cores that were drilled in different years show no significant difference. This means that there is no systematic attenuation of the seasonal $\delta^{18} \mathrm{O}$ signal during the first 20 years following the deposition year.

Changes in the seasonal distribution of accumulation can lead to a bias in the isotopic record of an ice core. This was studied quantitatively on a short time-scale, using the available high-time-resolution data of accumulation, stable-isotope content and air temperature. Mean annual $\delta^{18} \mathrm{O}$ values from firn cores at Neumayer are badly correlated to annual mean air temperatures $(r=-0.13)$. This is due to variations of the seasonal distribution of accumulation. At Neumayer, the cyclonic activity in late winter and early spring mainly determines whether the core data are biased and in which direction. The correlation improves $(r=0.38)$ if an accumulation-weighted temperature is used.

On a larger time-scale, a systematic shift in mean storm tracks (e.g. at the transition from an ice age to a warmer climate) could lead to a bias in stable-isotope content in ice cores and thus to errors in ice-core interpretation. However, our knowledge of seasonality of accumulation in former climates is poor. The results from Neumayer should be combined with a general circulation model or regional Antarctic atmospheric model study for different climates in order to investigate how to interpret the isotopic record of a DML ice core with respect to temperature change.

\section{ACKNOWLEDGEMENTS}

Thanks are due to all colleagues who carried out the fieldwork at Neumayer and the analysis of the snow samples and firn cores at the Alfred Wegener Institute (AWI). Part of this analysis was done by W. Graf at GSF, Institute for Hydrology, Neuherberg, Germany, We would like to thank G. KönigLanglo of AWI for kindly providing the meteorological data from Neumayer. This study has received financial support from the Austrian Science Fund (grant No. P13429-GEO).

\section{REFERENGES}

Dansgaard,W. 1964. Stable isotopes in precipitation. Tellus, 16(4), 436-468.

Graf, W. and 6 others. 1994. Snow-accumulation rates and isotopic content $\left({ }^{2} \mathrm{H},{ }^{3} \mathrm{H}\right)$ of near-surface firn from the Filchner-Ronne Ice Shelf, Antarctica. Ann. Glaciol., 20, 121-128.

Graf, W. and 6 others. 2002. Stable isotope records from Dronning Maud Land, Antarctica. Ann. Glaciol., 35 (see paper in this volume).

Isaksson, E. and W. Karlén. 1994. High resolution climatic information from short firn cores, western Dronning Maud Land, Antarctica. Climatic Change, 26(4), 421-434.

Johnsen, S. J. 1977. Stable isotope homogenization of polar firn and ice. International Association of Hydrological Sciences Publication 118 (Symposium at Grenoble 1975 - Isotopes and Impurities in Snow and Ice), 210-219.

Johnsen, S. J. and G. de Q. Robin. 1983. Diffusion of stable isotopes. In Robin, G. de Q., ed. The climatic record in polar ice sheets. Cambridge, Cambridge University Press, 57-63.

Jones, P. D., R. Marsh, T. M. L. Wigley and D. A. Peel. 1993. Decadal timescale links between Antarctic Peninsula ice-core oxygen-18, deuterium and temperature. Holocene, 3(1), 14-26.

Jouzel, J., L. Merlivat, J. R. Petit and C. Lorius. 1983. Climatic information over the last century deduced from a detailed isotopic record in the South Pole snow. F. Geophys. Res., 88(C4), 2693-2703.

Jouzel, J. and 12 others. 1997. Validity of the temperature reconstruction from water isotopes in ice cores. 7. Geophys. Res., 102(C12), 26,471-26,487.

King, J. C. and J. Turner. 1997. Antarctic meteorology and climatology. Cambridge, Cambridge University Press.

König-Langlo, G. and B. Marx. 1997. The meteorologicalinformation system at the Alfred-Wegener Institute. In Lautenschlager, M. and M. Reinke, eds. Climate and environmental database systems. Dordrecht, etc., Kluwer Academic Publisher, 117-125.

Krinner, G. 1997. Simulations du climat des calottes de glace. (Ph.D. thesis, Université Joseph Fourier — Grenoble I.)

Noone, D. and I. Simmonds. 1998. Implications for the interpretation of icecore isotope data from analysis of modelled Antarctic precipitation. Ann. Glaciol., 27, 398-402.

Noone, D., J. Turner and R. Mulvaney. 1999. Atmospheric signals and characteristics of accumulation in Dronning Maud Land, Antarctica. F. Geophys. Res., 104(D16), 19,191-19,211.

Oerter, H., W. Graf, F. Wilhelms, A. Minikin and H. Miller. 1999. Accumulation studies on Amundsenisen, Dronning Maud Land, by means of tritium, dielectric profiling and stable-isotope measurements: first results from the 1995-96 and 1996-97 field seasons. Ann. Glaciol., 29, 1-9.

Peel, D. A. 1992. Ice core evidence from the Antarctic Peninsula region. In Bradley, R. S. and P. D. Jones, eds. Climate since A.D. 1500. London and New York, Routledge, 549-571.

Peel, D. A., R. Mulvaney and B. M. Davison. 1988. Stable-isotope/air-temperature relationships in ice cores from Dolleman Island and the Palmer Land plateau, Antarctic Peninsula. Ann. Glaciol., 10, 130-136.

Pfaff, C. 1993. ${ }^{2} \mathrm{H}$ - und ${ }^{18} \mathrm{O}-$ Gehalte in den Niederschlägen in Abhängigkeit von der meteorologischen Situation im Bereich der Georg-vonNeumayer-Station, Antarktis. (Ph.D. thesis, University of Innsbruck.)

Picciotto, E., X. de Maere and I. Friedmann. 1960. Isotope composition and temperature of formation of Antarctic snows. Nature, 187(4740), 857-859.

Reijmer, C. H. and M. R. van den Broeke. 2001. Moisture sources of precipitation in western Dronning Maud Land, Antarctica. Antarct. Sci., 13(2), 210-220.

Reinwarth, O., W. Graf, W. Stichler, H. Moser and H. Oerter. 1985. Investigations of the oxygen-18 content of samples from snow pits and ice cores from the Filchner-Ronne ice shelves and Ekström ice shelf. Ann. Glaciol., 7, 49-53.

Robin, G. de Q. 1983. The climatic record from ice cores. The $\delta$ value-temperature relationship. In Robin, G. de Q., ed. The climatic record in polar ice sheets. Cambridge, Cambridge University Press, 180-184.

Schlosser, E. 1999. Effects of seasonal variability of accumulation on yearly mean $\delta^{18} \mathrm{O}$ values in Antarctic snow. f. Glaciol., 45(151), 463-468.

Schlosser, E. and H. Oerter. 2002. Shallow firn cores from Neumayer, Ekströmisen, Antarctica: a comparison of accumulation rates and stable isotope ratios. Ann. Glaciol., 35 (see paper in this volume).

Schlosser, E., H. Oerter andW. Graf. 1999. Surface mass balance investigations on Ekströmisen, Antarctica, 1980-1996. Ber. Polarforsch./Rep. Pol. Res. 313.

Schwerdtfeger, W. 1984. Weather and climate of the Antarctic. Amsterdam, Elsevier. (Developments in Atmospheric Science 15.)

Van Loon, H. 1967. The half-yearly oscillations in middle and high southern latitudes and the coreless winter. 7. Atmos. Sci., 24(5), 472-486. 